The Chittagong Univ. J. Sci. 41(1) : 68-84, 2019

DOI: https://doi.org/10.3329/cujs.v41i1.51915

\title{
Synthesis and Biological Evaluation of Sugar Induced Thiazole Derivatives
}

\author{
Md. Mosharef Hossain Bhuiyan ${ }^{1 *}$, Mohammed M. Matin ${ }^{1}$, \\ A. F. M. Hafizur Rahman ${ }^{2}$ and Md. Rabiul Alam ${ }^{3}$ \\ ${ }^{I}$ Department of Chemistry, University of Chittagong, Chittagong-4331, Bangladesh \\ ${ }^{2}$ Department of Analytical Chemistry \& Environmental Science, Training Institute \\ for Chemical Industries (TICI), Polash, Norsingdi-1611, Bangladesh \\ ${ }^{3}$ Department of Chemistry, Comilla University, Kotbari, Cumilla, Bangladesh \\ *Corresponding author: mosharefchem@cu.ac.bd
}

\begin{abstract}
The starting materials, 2-amino-4-phenylthiazole and 2-amino-4,5,6,7tetrahydrobenzo[d]thiazole, were prepared by reacting thiourea with acetophenone and cyclohexanone in the presence of iodine under heating on a water bath with occasional stirring, respectively. Reaction of 2-amino-4-phenylthiazole and 2amino-4,5,6,7-tetrahydrobenzo[d]thiazole with various sugars afforded corresponding $\mathrm{N}$-glycoside derivatives in good yields. The structures of the synthesized $\mathrm{N}$-glycosides derivatives have been established on the basis of their IR and NMR spectral data. The obtained compounds were screened for their antimicrobial activity. Some of them were found to possess significant activities, when compared to standard drugs.

Keywords: Aminothiazole, sugar, $N$-Glycoside, antimicrobial activity.

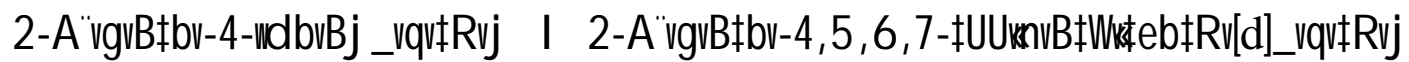

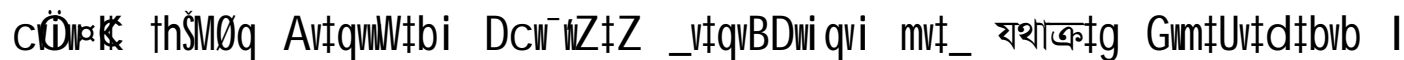




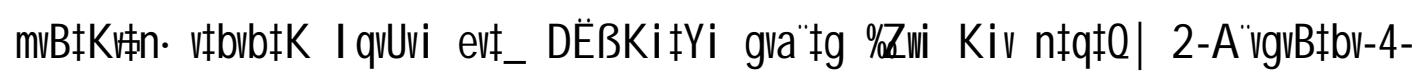

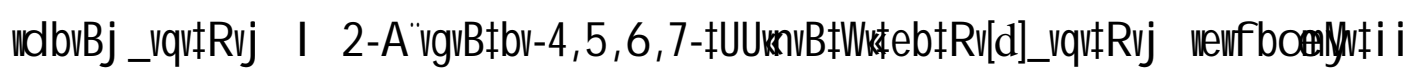
nस_ বিক্রিয়ার মাধ্যłg Abiffc $N$-M

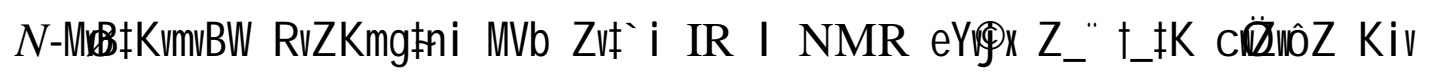

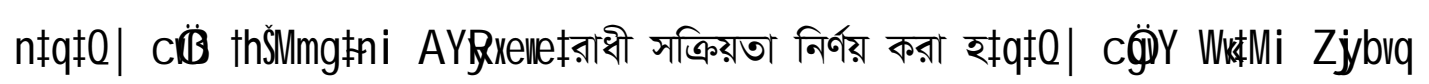
VKQ

\section{Introduction}

Heterocyclic compounds are widely distributed in nature and occupy a prominent place in medicinal chemistry as pharmaceuticals and drug intermediates [1]. They play a significant role in the metabolism of all living cells and many are clinically used for the treatment of various diseases. The therapeutic importance of heterocycles has generated much interest in the synthesis of new classes of heterocyclic systems in order to explore their biodynamic properties [2]. Various heterocycles those are used for developing pharmaceutically important molecules, thiazoles, fused thiazoles, and thiazoles linked to various heterocylic rings through different linkages have recently attracted great attention [3]. These were found to be associated with a wide range of chemotherapeutic activities including antimicrobial [4-6], antifungal [7,8], antiparasitic [9], and antiviral [10,11] activities. On the other hand, thiazole-containing compounds were reported to contribute to a variety of anticancer potentials including antitumor [12,13], cytotoxic [14,15], antiproliferative [16,17], DNA-cleaving [18,19], and angiogenesis inhibiting [20] activities. Interest in the chemotherapeutic activity of thiazoles was potentiated after the discovery of the natural antineoplastic antibiotics 
tiazofurin [21,22], bleomycin, netropsin, and thiazole netropsin [23]. Most of these natural drugs have the thiazole carboxamide moiety as a common feature.

$\mathrm{N}$-Glycosides belong to the compounds with a wide range of biological activities. Some $\mathrm{N}$-glycosides show antineoplastic effects [24]. The indigo $\mathrm{N}$-glycosides (blue sugar), the analogues of naturally occurring akashins [25] showed considerable effect against various human cancer cell. As a review article [26] summarizes the synthesis, structure and evaluation of biological activities of the $\mathrm{N}$-glycosides containing quinazoline skeleton has been published. Therefore the synthesis of new $\mathrm{N}$-glycosides based compounds is an actual topic.

Based on the above facts and as a continuation of our ongoing program on thiazole derivatives $[27,28]$, the present work describes the synthesis, characterization and antimicrobial evaluation of some new $\mathrm{N}$-glycosides having substituted thiazole moiety.

\section{Experimental}

Melting points were recorded with Electrothermal melting point apparatus and are uncorrected. Evaporation of solvents was performed under reduced pressure on a Buchi rotary evaporator. Thin layer chromatography was performed on Kieselgel GF254 and visualization was accomplished by Iodine Flask or UV Lamp. Column chromatography was carried out with silica gel G60 (100-200 mesh). ${ }^{1} \mathrm{H}-\mathrm{NMR}$ (400 MHz) and ${ }^{13} \mathrm{C}-\mathrm{NMR}(100 \mathrm{MHz})$ spectra were recorded for solutions in deuterioted chloroform $\mathrm{CDCl}_{3}$ as solvent. Chemical shifts were reported in $\delta$ unit (ppm) with reference to TMS as an internal standard. 


\section{Preparation of 2-amino-4-phenyl-(1,3)-thiazole (1):}

Thiourea (15.20 gm $200 \mathrm{mmol})$, and iodine (25.20 gm $200 \mathrm{mmol})$ were triturated and mixed with acetophenone $(11.65 \mathrm{ml}, 100 \mathrm{mmol})$. The mixture was heated on a water bath with occasional stirring for about 8 hours. The conversion was checked by TLC (ethyl acetate: $n$-hexane, 1:6, v/v) on silica gel which showed conversion of starting material into one moving faster product. The product was cooled and the obtained solid was triturated with diethyl ether solution to remove unreacted acetophenone. Then washed with aqueous sodium thiosulphate solution to remove excess of iodine and then with water. The crude product was dissolved in hot water, filter to remove sulphone and required 2-amino-4-phenyl-(1,3)-thiazole, 1 was precipitated by addition of $\mathrm{NH}_{3} \times \mathrm{H}_{2} \mathrm{O}$. The obtained precipitated was recrystallized from ethanol to give the white solid crystals, yield 65\%, mp 146-148 ${ }^{\circ} \mathrm{C}$.

IR: $3420,3240,1600,770,710 \mathrm{~cm}^{-1}$

${ }^{1} \mathrm{H}$ NMR: $\delta 7.87$ (m, 2H, aromatic), 7.54 (m, 3H, aromatic), 7.47 (s, 1H, thiazole-H)

${ }^{13} \mathrm{C}-\mathrm{NMR}: \delta$ 170.03, 149.30, 137.32, 128.7, 127.5, 126.6, 102.9

\section{Preparation of 2-amino-4,5,6,7-tetrahydrobenzo[d]thiazole (2):}

The titled compound was prepared from cyclohexanone using same procedure as mentioned for the synthesis of compound $\mathbf{1}$ and recrystallized from ethanol as white solid crystals, yield $85 \%$ and $\mathrm{mp} 188-190{ }^{\circ} \mathrm{C}$.

IR (KBr): $v_{\max } 3261.40,3130.25,29.35 .46,1612.38,1519 \mathrm{~cm}^{-1}$.

${ }^{1} \mathrm{H}$ NMR: $\delta 4.90$ (hump, 2H, $\mathrm{NH}_{2}$ ), $2.50\left(\mathrm{~m}, 4 \mathrm{H}, 2 \times \mathrm{CH}_{2}\right), 1.81\left(\mathrm{~m}, 4 \mathrm{H}, 2 \times \mathrm{CH}_{2}\right)$.

${ }^{13} \mathrm{C}-\mathrm{NMR}: \delta 169.75,139.39,117.32,25.51,24.09,23.62,23.24$. 
Synthesis and Biological Evaluation of Sugar Induced Thiazole Derivatives

\section{General procedure for synthesis of $N$-Glycosides}

A mixture of thiazolo amine 1 or $2(1.0 \mathrm{mmol})$ and sugar $(1.5 \mathrm{mmol})$ was refluxed in methanol $(8 \mathrm{ml})$ in the presence of acetic acid $(0.3 \mathrm{ml})$ for $8-10 \mathrm{hrs}$. The progress of reaction was checked by TLC (methanol : chloroform, 1:8, v/v) on silica gel. A slower moving spot indicated the conversion of reaction and formation of the product. Mixture was then cooled and purified by column chromatography. Recrystallization was carried out with proper solvent.

\section{2-[N-(D)-Glucopyranosyl]amino-4-phenyl-(1,3)-thiazole (3):}

Brownish solid crystal, mp 120-124 ${ }^{\circ} \mathrm{C}$, yield: $65 \%$.

IR (KBr): $v_{\max } 3500-3200,2935,1630,1527 \mathrm{~cm}^{-1}$.

${ }^{1} \mathrm{H}-\mathrm{NMR}: \delta 7.36(\mathrm{~m}, 3 \mathrm{H}, \mathrm{Ar}-\mathrm{H}), 7.28$ (d, 2H, J=7.56 Hz, Ar-H), 7.14 (s, 1H, -CH,

Thiazole), 5.33 (d, 1H, $J=5.4$ Hz, H-1), 4.67 (m, 1H, H-5), 4.4 (hump -NH), 3.63

(dd, $1 \mathrm{H}, J=11.6$ and $5.4 \mathrm{~Hz}, \mathrm{H}-2), 3.48(\mathrm{t}, 1 \mathrm{H}, J=9.6 \mathrm{~Hz}, \mathrm{H}-3), 3.25$ (m, 1H, H4), 3.14 (m, 2H, H-6), 1.89 (s, 4H, OH).

${ }^{13} \mathrm{C}-\mathrm{NMR}: \delta 168.01$ (C-2, thiazole), 149.6 (C-4, thiazole), 134.8 (C-1, Ph), 128.5 (C-3\&5, Ph), 127.3 (C-4, Ph), 125.5 (C-2\&6, Ph), 102.7 (C-5, thiazole), 85.8 (anomeric), 78.3, 76.8, 72.7, 70.3, $60.8\left(\mathrm{CH}_{2}\right)$.

\section{2-[N-(D)-Galactopyranosyl]amino-4-phenyl-(1,3)-thiazole (4):}

Brownish coloured solid crystal, mp $128-130{ }^{\circ} \mathrm{C}$, yield: $65 \%$.

IR (KBr): $v_{\max } 3450-3210,2925,2862,1547 \mathrm{~cm}^{-1}$.

${ }^{1} \mathrm{H}-\mathrm{NMR}: \delta 7.37$ (m, 3H, Ar-H), 7.27 (d, 2H, $\left.J=7.02 \mathrm{~Hz}, \operatorname{Ar}-\mathrm{H}\right), 7.12$ (s, 1H, -CH, Thiazole), 4.84 (d, 1H, J=5.4 Hz, H-1), 4.67 (dd, $1 \mathrm{H}, J=8.64$ and $5.4 \mathrm{~Hz}, \mathrm{H}-2)$, 
4.63 (m, 2H, H-6), 4.4 (broad -NH), 3.71 (m, 1H, H-3), 3.44 (m, 2H, H-4 \& H-5), $3.35(\mathrm{~s}, \mathrm{OH})$.

${ }^{13} \mathrm{C}-\mathrm{NMR}: \delta 168.2,149.8,134.8,128.5,127.2,125.6,101.9,86.2,76.4,74.2,69.9$, $68.2,60.4$.

\section{2-[N-(D)-Rhamnopyranosyl]amino-4-phenyl-(1,3)-thiazole (5):}

Brownish colored solid crystal, mp $157-159^{\circ} \mathrm{C}$, yield: $60 \%$.

IR (KBr): $v_{\max } 3420-3200,2928,1629,1535 \mathrm{~cm}^{-1}$.

${ }^{1} \mathrm{H}-\mathrm{NMR}: \delta 7.38$ (m, 3H, Ar-H), 7.27 (d, 2H, J=7.02 Hz, Ar-H), 7.13 (s, 1H, -CH, Thiazole), 6.10 (dd, 1H, $J=8.10$ and $3.78 \mathrm{~Hz}, \mathrm{H}-3$ ), 5.07 (t, 1H, $J=9.18 \mathrm{~Hz}, \mathrm{H}-4$ ), $4.55(\mathrm{dd}, 1 \mathrm{H}, J=5.4$ and $4.05 \mathrm{~Hz}, \mathrm{H}-2), 4.48$ (m, 1H, H-5), 3.74 (hump -NH), 3.56 (d, 1H, $J=2.97 \mathrm{~Hz}, \mathrm{H}-1), 3.39$ (s, OH), 1.08 (d, 3H, $J=6.21 \mathrm{~Hz}$.).

${ }^{13}$ C-NMR: $\delta 167.3,149.6,134.8,128.6,127.4,125.7,102.8,94.1,73.5,72.4,70.4$, $67.8,18.1$.

\section{2-[N-(D)-Xylopyranosyl]amino-4-phenyl-(1,3)-thiazole (6):}

Brownish coloured solid crystal, mp $125-126^{\circ} \mathrm{C}$, yield: $65 \%$.

IR (KBr): $v_{\max } 34400-3260,2927,2860,1640 \mathrm{~cm}^{-1}$.

${ }^{1} \mathrm{H}-\mathrm{NMR}: \delta 7.36(\mathrm{~m}, 3 \mathrm{H}, \mathrm{Ar}-\mathrm{H}), 7.27$ (d, 2H, J=7.30 Hz, Ar-H), 7.15 (s, 1H, -CH, Thiazole), 5.0 (hump -NH), 4.62 (d, 1H, J = 2.97 Hz, H-1), 3.70 (m, 2H, H-5), 3.36 (m, 1H, H-4), 3.18 (t, 1H, J=4.00 Hz, H-2), 3.10 (t, 1H, J=4.00 Hz, H-3), 1.89 (s, $\mathrm{OH})$.

${ }^{13}$ C-NMR: $\delta 167.9,149.8,134.7,128.5,127.4,125.6,102.1,86.5,77.6,72.6,69.7$, 67.2. 
74 Synthesis and Biological Evaluation of Sugar Induced Thiazole Derivatives

Ash colored solid crystal, mp $160-162{ }^{\circ} \mathrm{C}$, yield: $60 \%$.

IR (KBr): $v_{\max } 3450-3250,2928,2852,1568 \mathrm{~cm}^{-1}$.

${ }^{1} \mathrm{H}-\mathrm{NMR}: \delta 7.37$ (m, 3H, Ar-H), 7.27 (d, 2H, J =7.00 Hz, Ar-H), 6.9 (s, 1H, -CH, Thiazole), 5.28 (d, 1H, $J=8.90 \mathrm{~Hz}, \mathrm{H}-1$ ), 4.8 (hump -NH), 4.63 (t, 1H, $J=8.10$ Hz, H-2), 3.79 (m, 1H, H-5), 3.66 (m, 1H, H-3), 3.50 (m, 1H, H-4), 1.89 (s, OH).

${ }^{13}$ C-NMR: $\delta, 168.2,149.7,134.8,128.5,127.3,125.6,102.1,86.1,73.4,69.9$, 67.9, 66.7.

\section{2-[N-(D)-Glucopyranosyl]amino-4,5,6,7- tetrahydrobenzothiazole (8):}

Reddish viscous liquid, yield $90 \%$.

IR (KBr): $v_{\max } 3500-3200,2925.81,1627.81,1527.62 \mathrm{~cm}^{-1}$.

${ }^{1} \mathrm{H}-\mathrm{NMR}: \delta 4.88$ (d, 1H, $J=5.4 \mathrm{~Hz}, \mathrm{H}-1$ ), 4.54 (m, 1H, H-5), 4.46 (hump, 1H, $\mathrm{NH}), 3.64(\mathrm{dd}, 1 \mathrm{H}, J=11.3$ and $5.4 \mathrm{~Hz}, \mathrm{H}-2), 3.39(\mathrm{t}, 1 \mathrm{H}, J=9.6 \mathrm{~Hz}, \mathrm{H}-3), 3.22$

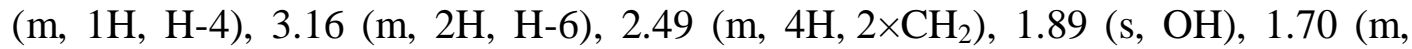
$\left.4 \mathrm{H}, 2 \times \mathrm{CH}_{2}\right)$.

${ }^{13}$ C-NMR: $\delta 165.18,144.61,115.13,85.25,78.01,77.74,77.54,72.35,69.99$, $26.38,23.18,22.68,22.52$.

\section{2-[N-(D)-xylopyranosyl]amino-4,5,6,7- tetrahydrobenzothiazole (9):}

Reddish viscous liquid, yield $87 \%$.

IR (KBr): v $v_{\max } 3500-3250,2921.96,2852.52,1637.45 \mathrm{~cm}^{-1}$.

${ }^{1} \mathrm{H}-\mathrm{NMR}$ : $\delta 4.96$ (hump, 1H, NH), 4.84 (d, 1H, H-1, J = 4.30 Hz), 3.96 (m, 2H, H-5), $3.69(\mathrm{dd}, 1 \mathrm{H}, J=6.75$ and $1.60 \mathrm{~Hz}, \mathrm{H}-2), 3.65$ (t, $1 \mathrm{H}, J=7.00 \mathrm{~Hz}, \mathrm{H}-3), 3.40$ (m, 1H, H-4), 2.49 (m, 4H, 2×CH $\mathrm{CH}_{2}, 1.69$ (br, OH), 1.15 (m, 4H, $2 \times \mathrm{CH}_{2}$ ). 
Md. Mosharef Hossain Bhuiyan, Mohammed M. Matin, A. F. M. Hafizur Rahman and Md. Rabiul Alam 75

${ }^{13} \mathrm{C}-\mathrm{NMR}: \delta 165.18,144.61,115.13,85.25,78.80,75.69,75.11,62.90,39.20$, $38.57,22.67,15.17$.

2-[N-(L)-arabinopyranosyl]amino-4,5,6,7- tetrahydrobenzothiazole (10):

Reddish viscous liquid, yield $89 \%$.

IR (KBr): $v_{\max } 3500-3250,2920.03,2850.59,1564.16 \mathrm{~cm}^{-1}$.

${ }^{1} \mathrm{H}-\mathrm{NMR}: \delta 5.12$ (hump -NH), 4.80 (d, 1H, J = $\left.8.90 \mathrm{~Hz}, \mathrm{H}-1\right), 4.53$ (m, 2H, H-5), $3.61(\mathrm{t}, 1 \mathrm{H}, J=12.40 \mathrm{~Hz}, \mathrm{H}-2), 3.42$ (m, 1H, H-3), 3.20 (m, 1H, H-4), 2.49 (m, 4H, $\left.2 \times \mathrm{CH}_{2}\right), 2.00(\mathrm{~s}, \mathrm{OH}), 1.71\left(\mathrm{~m}, 4 \mathrm{H}, 2 \times \mathrm{CH}_{2}\right)$.

${ }^{13}$ C-NMR: $\delta$ 164.84, 144.70, 115.21, 85.57, 73.28, 69.87, 67.7, 66.18, 26.34, 23.14, $22.65,22.48$.

2-[N-(D)-galactopyranosyl]amino-4,5,6,7-tetrahydrobenzothiazole (11):

Reddish viscous liquid, yield $82 \%$.

IR (KBr): $v_{\max } 3487-3217,2920.03,2850.59,1542.95 \mathrm{~cm}^{-1}$.

${ }^{1} \mathrm{H}-\mathrm{NMR}: \delta 4.56(\mathrm{~d}, 1 \mathrm{H}, J=8.60 \mathrm{~Hz}, \mathrm{H}-1), 4.36(\mathrm{dd}, 1 \mathrm{H}, J=8.60$ and $5.40 \mathrm{~Hz}, \mathrm{H}-$ 2), 4.60 (m, 2H, H-6), 4.4 (broad -NH), 3.68 (m, 1H, H-3), 3.33 (m, 2H, H-4 \& H5), $2.49\left(\mathrm{~m}, 4 \mathrm{H}, 2 \times \mathrm{CH}_{2}\right), 1.89(\mathrm{~s}, \mathrm{OH}), 1.11\left(\mathrm{t}, 4 \mathrm{H}, 2 \times \mathrm{CH}_{2}, J=7.02 \mathrm{~Hz}\right)$.

${ }^{13} \mathrm{C}-\mathrm{NMR}: \delta$ 165.17, 144.61, 119.98, 85.66, 77.21, 76.15, 74.24, 72.17, 68.15, $26.38,23.15,22.67,22.49$.

\section{Antimicrobial Screening}

Materials and Methods 
76 Synthesis and Biological Evaluation of Sugar Induced Thiazole Derivatives

The antibacterial activities of thiazolo sugar derivatives were studied against six bacteria and antifungal activities of the same compounds were also studied against five fungi. For the detection of antibacterial activity, the disc diffusion method [29] was followed. The antifungal activity was assessed by poisoned food technique [30].

\section{Name of the organism:}

\section{Bacteria:}
i) Bacillus cereus
BTCC 19
Gram-Positive
ii) Bacillus subtilis
Gram-Positive
iii) Staphylococcus aureus
ATCC 6538
Gram- Negative
iv) Shigella dysenteriae
AE 14396
Gram-Negative
v) Salmonella typhi
AE 14612
Gram-Negative
vi) Pseudomonous sp.
Gram-Negative

2. Fungi:
i) Aspergillus niger
ii) Penicillium notatum
iii) Aspergillus funiculosus
iv) Collectotrichum corchori Ikata (Yoshida).
v) Curvularia lunata

\section{Disc Diffusion method:}


Paper disc of $4 \mathrm{~mm}$ in diameter and Petri plate of $100 \mathrm{~mm}$ in diameter were used throughout the experiment culture plated were made with sterilized methods NA $\left(45^{\circ} \mathrm{C}\right)$ and after solidification of agar medium, the test organizations (suspensions) were pressed uniformly over the plate with sterilized glass rod separately. The paper discs after soaking with test chemicals at the rate $10 \mathrm{mg} / \mathrm{disc}(100 \mathrm{mg} / \mathrm{disc})$ were placed at the center on the inoculated pour plate. A control plate was also maintained in each case with DMF. These were kept for 4 hours at low temperature $\left(4{ }^{\circ} \mathrm{C}\right.$ ) and test chemicals diffused from disc to the surrounding medium by this time. The plates were than incubated at $(35 \pm 2){ }^{\circ} \mathrm{C}$ for growth of test organisms and were observed at 24 hours intervals for two days. The activity is expressed in terms of diameters of 24 hours intervals for two days. The activity is expressed in terms of diameters of zone of inhibition in $\mathrm{mm}$. Each experiment was reported thrice.

Table 1: Inhibition against the Gram-Positive and Gram-Negative organisms by the test chemicals.

\begin{tabular}{|c|c|c|c|c|c|c|}
\hline \multirow{2}{*}{$\begin{array}{c}\text { Compound } \\
\text { No. }\end{array}$} & \multicolumn{6}{|c|}{ Diameter of zone of inhibition in mm(100 mg (dw)/ disc) } \\
\cline { 2 - 7 } & $\begin{array}{l}\text { B. } \\
\text { cereus }\end{array}$ & $\begin{array}{l}\text { B. } \\
\text { subtilis }\end{array}$ & S. aureus & $\begin{array}{l}\text { S. } \\
\text { dysenteria }\end{array}$ & S. typhi & $\begin{array}{l}\text { Pseudomonous } \\
\text { sp. }\end{array}$ \\
\hline $\mathbf{3}$ & 12 & 14 & 18 & 10 & 9 & 14 \\
\hline $\mathbf{4}$ & $\ldots$ & 8 & $\ldots$ & $\ldots$ & 7 & $\ldots$ \\
\hline $\mathbf{5}$ & $\ldots$ & $\ldots$ & 7 & $\ldots$ & $\ldots$ & 8 \\
\hline $\mathbf{6}$ & 14 & 9 & 12 & 14 & 12 & 17 \\
\hline $\mathbf{7}$ & 8 & 11 & 9 & 12 & 9 & 14 \\
\hline $\mathbf{8}$ & 10 & 12 & 14 & 7 & 7 & 10 \\
\hline $\mathbf{9}$ & 12 & 8 & 10 & 11 & 12 & 13 \\
\hline $\mathbf{1 0}$ & 8 & 10 & 8 & 10 & $\ldots$ & 12 \\
\hline $\mathbf{1 1}$ & $\ldots$ & 6 & $\ldots$ & $\ldots$ & 6 & $\ldots$ \\
\hline $\begin{array}{l}\text { Ampicillin } \\
25 \mu \mathrm{g}(\mathrm{dw}) / \mathrm{disc}\end{array}$ & 21 & 19 & 29 & 30 & 24 & 27 \\
\hline
\end{tabular}

N.B.:- '(...)’ Means no inhibition, dw. Denotes dry weight.

Food poison technique: 
78 Synthesis and Biological Evaluation of Sugar Induced Thiazole Derivatives

The test chemicals (1\%) were mixed with sterilized potato dextrose agar (PDA) medium $\left(42{ }^{\circ} \mathrm{C}\right)$ of the rate $100 \mathrm{mg} / \mathrm{ml}$ PDA. The medium was poured in sterilized patriplate and after solidification the equal diameter of fungal inoculums block (10 $\mathrm{mm}$ mycelial block) was pleased on the center of the petriplates. Radial growth of fungal colony was measured in mm after 3-5 of incubation at $(25 \pm 2)^{\circ} \mathrm{C}$ a control set was maintained in each experimental using only PDA with DMF of $1 \%$ as growth medium. Each experiment repeated thrice. The percentage inhibition of mycelial growth of the test fungi was calculated as follows:

$$
I=\frac{(C-T)}{C} \times 100
$$

\section{Where,}

$$
\begin{aligned}
& \mathrm{I}=\text { Percentage of inhibition } \\
& \mathrm{C}=\text { Diameter of the fungal colony in control (DMF) } \\
& \mathrm{T}=\text { Diameter of the fungal colony in treatment. }
\end{aligned}
$$

Table 2: Percent inhibitions of mycelial growth of treated with different chemicals $(100 \mathrm{mg}(\mathrm{dw}) / \mathrm{ml}$ PDA) develop in organic laboratory.

\begin{tabular}{|l|l|}
\hline Comp. & $\%$ inhibition of mycelial growth $(100 \mu \mathrm{g}(\mathrm{dw}) \mathrm{ml}$ PDA \\
\hline
\end{tabular} 
Md. Mosharef Hossain Bhuiyan, Mohammed M. Matin, A. F. M. Hafizur Rahman and Md. Rabiul Alam 79

\begin{tabular}{|c|c|c|c|c|c|}
\hline No. & $\begin{array}{l}\text { Aspergillus } \\
\text { niger }\end{array}$ & $\begin{array}{l}\text { Penicillium } \\
\text { notatum }\end{array}$ & $\begin{array}{l}\text { Aspergillus } \\
\text { funiculosus }\end{array}$ & $\begin{array}{l}\text { Colletotrichum } \\
\text { corchori }\end{array}$ & $\begin{array}{l}\text { Curvularia } \\
\text { lunata }\end{array}$ \\
\hline $\mathbf{3}$ & 49.25 & $* 65.38$ & $* 65.62$ & 40.90 & $* 72.24$ \\
\hline $\mathbf{4}$ & $* 68.96$ & 57.69 & 59.37 & $* 54.54$ & $* 73.83$ \\
\hline $\mathbf{5}$ & 58.62 & 50.00 & $* 68.75$ & 45.45 & 66.76 \\
\hline $\mathbf{6}$ & 62.09 & $* 61.54$ & 46.75 & 49.11 & 69.88 \\
\hline $\mathbf{7}$ & 58.62 & 43.43 & 43.75 & 40.91 & $* 70.26$ \\
\hline $\mathbf{8}$ & 40.20 & 55.30 & 60.60 & 35.65 & 60.50 \\
\hline $\mathbf{9}$ & 45.30 & 54.20 & 40.55 & 45.35 & 60.20 \\
\hline $\mathbf{1 0}$ & 50.45 & 40.30 & 35.85 & 38.20 & 58.40 \\
\hline $\mathbf{1 1}$ & 53.85 & 49.80 & 45.50 & 47.10 & 60.45 \\
\hline $\begin{array}{c}\text { Nystatin } \\
100 \mu \mathrm{g}\end{array}$ & 71.78 & 61.55 & 54.70 & 54.51 & 75.00 \\
$(\mathrm{dw}) / \mathrm{PDA}$ & & & & & \\
\hline
\end{tabular}

N.B :- ‘*’ Means good inhibition, dw. Denotes dry weight.

\section{Results and Discussion}

The starting materials, 2-amino-4-phenylthiazole (1) and 2-amino-4,5,6,7tetrahydrobenzo[d]thiazole (2), were prepared by reacting thiourea with acetophenone and cyclohexanone in the presence of iodine under heating on a water bath with occasional stirring, respectively. These were then reacted with various sugars in methanol in presence of acetic acid under reflux condition to produce $N$-glycoside derivatives (3-11) (Scheme 1).<smiles>CC(=O)c1ccccc1</smiles>

i. $\mathrm{Et}_{2} \mathrm{O}$

ii. $\mathrm{Na}_{2} \mathrm{~S}_{2} \mathrm{O}_{3}$

iii. $\mathrm{NH}_{3}, \mathrm{H}_{2} \mathrm{O}$<smiles>Nc1nc(-c2ccccc2)cs1</smiles> 
80 Synthesis and Biological Evaluation of Sugar Induced Thiazole Derivatives

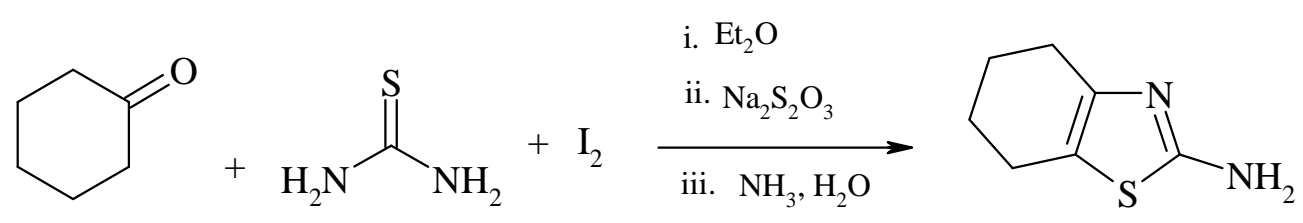

2
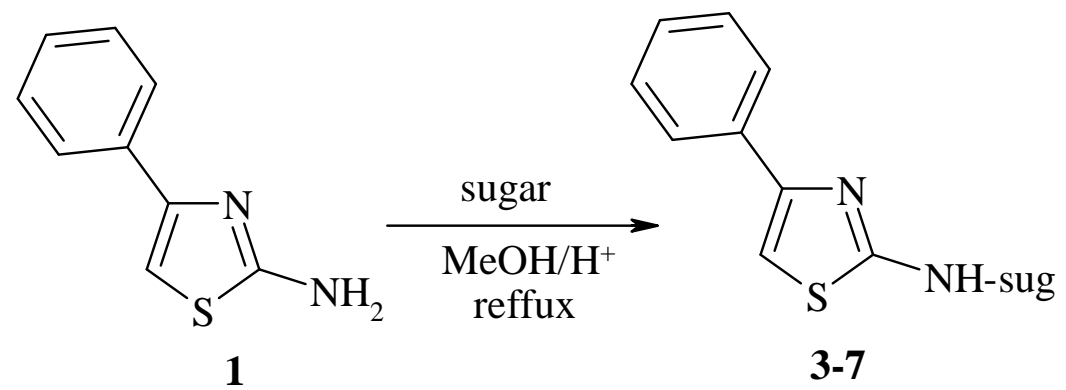

3-7

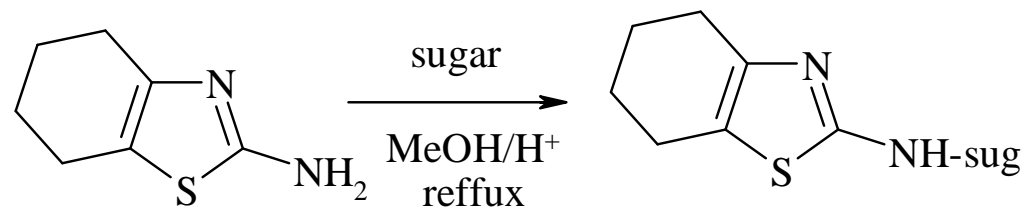

2

8-11

3: $\operatorname{sug}=\mathrm{D}$-glucose; 4: $\operatorname{sug}=\mathrm{D}$-galactose; 5: sug = L-rhamnose; 6: $\operatorname{sug}=\mathrm{D}$-xylose; 7: sug = L-arabinose; 8: sug = D-glucose; 9: $\operatorname{sug}=\mathrm{D}$-xylose; 10: $\operatorname{sug}=\mathrm{L}$ arabinose; 11: $\operatorname{sug}=\mathrm{D}$-galactose

\section{Scheme 1}

The structures of the synthesized glycosides containing thiazolo moiety were confirmed from their IR and NMR spectral data.

For example in the ${ }^{1} \mathrm{H}-\mathrm{NMR}$ of compound 3 the appearance of $\mathrm{H}-1$ at $\delta 5.33$ as doublet with small coupling constant $(J=5.4 \mathrm{~Hz})$ indicated that it is equatorially oriented. So, the glycosidic (C-1) thiazoloamine group must be $\alpha$. H-2 proton 
appeared at $\delta 3.63$ as dd with $J$ values of 11.6 and $5.4 \mathrm{~Hz}$. Other peaks are also in accordance with the assigned structure. In the ${ }^{13} \mathrm{C}-\mathrm{NMR}$ spectrum the anomeric carbon appeared at $\delta 85.8$. Other carbons of the sugar moiety appeared at $\delta 78.3$, $76.8,72.7,70.3,60.8$ respectively. Similarly, structures of the rest compounds were confirmed from their spectral data.

The synthesized products were screened for antibacterial activity against six human pathogenic bacteria, viz. Bacillus cereus, Bacillus subtilis, Staphylococcus aureus, Shigella dysenteria, Salmonella typhi and Pseudomonous sp. (Table 1). For antifungal activities of the same chemicals were also studied against five phytopathoganic fungi. viz. Aspergillus niger, Penicillium notatum, Aspergillus funiculosus, Collectrocium chorcori, Curvularia lunata (Table 2). Some of the synthesized compounds exhibited poor antibacterial activities but most of the compounds exhibited pronounced antifungal activities.

\section{Conclusion}

In this work, we have demonstrated the syntheses of sugar induced $N$-glycosides with promising antibacterial and antifungal activity. The activity data obtained during the study will be certainly useful to go for further research for drug designing and synthesizing new thiazole derivatives.

\section{Acknowledgments}

The authors wish to thank Dr. A. Rahman, Department of Biochemistry and Molecular Biology, University of Chittagong, Bangladesh, for his cooperation in determining the antimicrobial activity of the synthesized compounds. We also wish to thank Dr. A. F. M. M. Rahman, JSPS Postdoctoral Fellow, Department of 
Chemistry, Shiga University of Medical Science, Japan for recording the spectral data. The authors also highly acknowledge the Ministry of Science and Technology, Bangladesh, (S1. No. 360, Phy's 6, Physical Science, 2015-2016), for financial support to carry out this project work.

\section{References:}

1. D. J. Brown, Pyrimidines and Their Benzo Derivatives, in Comprehensive Heterocyclic Chemistry, Ed. Katritzky, A. R. and Rees, C. W. Vol. 3, Pergamon Press, Oxford, 1984, p. 443.

2. R. Mishra, B. Mishra and N. S. H. N. Moorthy, Trends Appl. Sci. Res., 2008, 3(2), 203.

3. M. S. Al-Saadi, H. M. Faidallah and S. A. Rostom, Archiv der Pharmazie, 2008, 341(7), 424.

4. S. Bondock, W. Khalifa and A. A. Fadda, Eur. J. Med. Chem., 2007, 42(7), 948.

5. O. Bozdağ-Dündar, Ö. Özgen, A. Menteşe, N. Altanlar, O. Atl, E.Kendi and R. Ertan, Bioorg. Med. Chem., 2007, 15(18), 6012.

6. T. M. de Aquino, A. P. Liesen, R. E. da Silva, V. T. Lima, C. S. Carvalho, A. N. R. de Faria, J. M. de Araujo, J. G. de Lima, A. J. Alves and E. J. de Melo, Bioorg. Med. Chem., 2008, 16(1), 446.

7. H. Fahmy, Boll. Chim. Farm., 2000, 140(6), 422.

8. C.-L. Liu, Z.-M. Li and B. Zhong, J. Fluorine Chem., 2004, 125(9), 1287. 
Md. Mosharef Hossain Bhuiyan, Mohammed M. Matin, A. F. M. Hafizur Rahman and Md. Rabiul Alam 83

9. R. P. Tenório, C. S. Carvalho, C. S. Pessanha, J. G. de Lima, A. R. de Faria, A. N. J. Alves, E. J. de Melo and A. J. Goes, Bioorg. Med. Chem., lett., 2005, 15(10), 2575.

10. V. A. Ryabinin, A. N. Sinyakov, V. R. de Soultrait, A. Caumont, V. Parissi, O. D. Zakharova, E. L. Vasyutina, E. Yurchenko, R. Bayandin and S. Litvak, Eur. J. Med. Chem., 2000, 35(11), 989.

11. W.-L. Wang, D.-Y. Yao, M. Gu and M.-Z. Fan, Bioorg. Med. Chem. Lett., $2005,15,5284$.

12. H. I. El-Subbagh, W. A. El-Naggar and F. A. Badria, Med. Chem. Res., 1994, 3(36), 503.

13. H.El-Subbagh and A. Al-Obaid, Eur. J. Med. Chem., 1996, 31(12), 1017.

14. B. Jiang and X.-H. Gu, Bioorg. Med. Chem., 2000, 8(2), 363.

15. J. A. Yalowitz, K. Pankiewicz, S. E. Patterson and H. N. Jayaram, Canc. Lett., 2002, 181(1), 31.

16. L. Garuti, M. Roberti, A. Pession, E. Leoncini and S. Hrelia, Bioorg. Med. Chem. Lett., 2001, 11(24), 3147.

17. C. Bolos, K. Papazisis, A. Kortsaris, S. Voyatzi, D. Zambouli and D. Kyriakidis, J. Inorg. Biochem., 2002, 88(1), 25.

18. Z. Li, Q. Yang and X. Qian, Bioorg. Med. Chem., 2005, 13(16), 4864.

19. R. Cejudo, G. Alzuet, M. González-Alvarez, J. García-Gimenez, J.Borrás and M. Liu-González, J. Inorg. Biochem., 2006, 100(1), 70.

20. A. S. Kiselyov, E. Piatnitski, M. Semenova and V. V. Semenov, Bioorg. Med. Chem. Lett., 2006, B(3), 602.

21. M. F. Earle and R. I. Glazer, Canc. Res., 1983, 43(1), 133. 
84 Synthesis and Biological Evaluation of Sugar Induced Thiazole Derivatives

22. G. Tricot, H. N. Jayaram, G. Weber and R. Hoffman, Int. J. Cell Clon., 1990, 8(3), 161.

23. P. Callery and P. Gannett, In Foye's Principles of Medicinal Chemistry. Lippincott Williams \& Wilkins, Philadelphia, 2002, 938.

24. M.A. Abdo, M.F. Abdel-Mageed, M.A. Saleh and G.A. El-Hiti, Pol. J. Chem., 1995, 69, 583.

25. R.F. Maskey, I. Grun-Wollny, H. H. Fiebig and H. Laatsch, Angew. Chem. Int. Ed., 2002, 41(4), 597.

26. G.A. El-Hiti and M. F. Abdel-Mageed, Heterocycl., 2005, 65(12), 3007.

27. M. M. H. Bhuiyan and A. F. M. H. Rahman, J. Sci. Res., 2011, 3(1), 111.

28. M. M. H. Bhuiyan and A. S. M. M. Kamal, J. Chem., 2012, 2(1), 56.

29. A. W. Bauer, W. M. M. Kirby, J. C. Sherris and M. Turck, Am. J. Clin. Path., 1966, 45, 493.

30. R. K. Grover and J.D. Moore, Phytopath., 1962, 52, 876.

Manuscript received on 20 February, 2019, Revised manuscript received on 19 June, 2019 and accepted on 19 June, 2019

The Chittagong Univ. J. Sc. Vol. 41(1), 2019 